Article

\title{
Why Brexit Will Do Little to Change the Political Contours of the European Social Dimension
}

\author{
Paul Copeland \\ School of Politics and International Relations, Queen Mary University of London, London, E1 4NS, UK; \\ E-Mail: p.copeland@qmul.ac.uk
}

Submitted: 28 March 2018 | Accepted: 15 June 2019 | Published: 16 September 2019

\begin{abstract}
Integration within the European social dimension, understood as the EU's competence in the field of employment and social policy, has been fraught with obstacles. Divisions between the EU's Member States have limited integration and resulted in a complex and piecemeal system of governance that is low down on the EU's list of priorities. The UK is often regarded as a major obstacle limiting the scope of integration in the field and this is not without good reason. Historically, the UK has formed coalitions to block policy negotiations within the European Council and has pushed for minimal neoliberal obligations in the field. The UK's departure from the EU could result in a step-change for the European social dimension. However, as this article will argue, the UK's departure from the EU will do little to alter the current dominance of a neoliberal market-led ideology, as it currently transcends the political agency of the UK.
\end{abstract}

\section{Keywords}

Brexit; European integration; European social dimension; European Union; neoliberalism; social policy; United Kingdom

\section{Issue}

This article is part of the issue "The Impact of Brexit on EU Policies", edited by Ferdi De Ville (Ghent University, Belgium) and Gabriel Siles-Brügge (University of Warwick, UK).

(C) 2019 by the author; licensee Cogitatio (Lisbon, Portugal). This article is licensed under a Creative Commons Attribution 4.0 International License (CC BY).

\section{Introduction}

The European social dimension, understood as the EU's competence in the field of employment and social policy, represents a patchwork of governance tools from different ideological positions across the EU's political space. Comparing the EU's competence in the European social dimension to that of the Single European Market, it is evident that the EU's direct competence in the field is relatively weak. However, the EU's budgetary rules for Members of the Eurozone in the form of the Stability and Growth Pact place indirect pressures on the spending of EU welfare states, thereby highlighting the complexities posed in isolating and understanding policy areas within the EU as discrete entities. Meanwhile, since the late 1980 s the political contours of the European social dimension have shifted. During the late 1980s when the idea of a European social dimension was first proposed, it was guided and influenced by post-war Keynesian so- cial democracy. While post-war European social democracy accepted the logic of markets and capitalism, it believed that the state had a strong role to play in protecting individuals. This would involve, in part, the regulation of labour markets to prevent a competitive race to the bottom of employment standards, as well as protecting individuals from the peaks and troughs of the economic growth cycle. To varying degrees, post-war Keynesian European states constructed welfare policies that were designed to strike a balance between commodifying and de-commodify individuals. Commodification is to be understood as policies designed to make wages from employment the linchpin of a person's existence, while de-commodification refers to policies which enable individuals or families to uphold socially acceptable living standards independent of the market and its peaks and troughs (Esping-Andersen, 1990). However, this vision of a European social dimension did not last and by the mid-1990s post-war European social democracy 
both at the Member State and EU levels slowly shifted to accommodate neoliberalism, which in turn, was to guide the construction of the European social dimension. There remains some disagreement between scholars of the politics of the European social dimension. For example, Caporaso and Tarrow (2009) argue that the jurisprudence of the European Court of Justice (ECJ) and the national courts have progressively restructured the rules concerning the free movement of workers to incorporate social policy concerns. While this nuancing of the treaties and primary legislation is undeniably true, the process of European integration and thereby the European social dimension are underpinned by neoliberalism. In a similar logic, some scholars highlight various developments in the field as signalling the EU taking employment and social concerns more seriously (e.g., Zeitlin \& Vanhercke, 2017), but again the overall thrust of developments is towards neoliberal solutions to economic and social problems.

This article analyses the UK's political influence within the European social dimension, as well as the likely impact the UK's departure from EU will have on future integration. The analysis is guided by a historical institutionalist analysis of European integration. The core assumption of historical institutionalism is that institutions-comprised of formal and informal arrangements-matter, and of which the European social dimension is an example. While historical institutionalism offers a detailed conceptual toolkit surrounding the purpose, function and existence of institutions, this article focuses on the concept of path-dependency. Pathdependency argues that the policy choices made when an institution is being formed, or policy is being initiated, will have a continuing and largely determinate influence over the policy far into the future (Peters, Pierre, \& King, 2005). Once institutional architects make their initial policy and institutional choices, the patterns will persist unless there is some force sufficient to overcome the inertia created during the inception of the programme (Peters et al., 2005, p. 64). Inspired by this conceptual approach, this article argues that the UK has been a 'pivotal outlier' (De Ville \& Siles-Brügge, 2019) in the European social dimension, first, by blocking the social democratic vision that emerged during the late 1980s and second, by becoming supportive of a neoliberal vision for the field throughout 1997-2010. Meanwhile, since 2010 neoliberalism has been consolidated within the European social dimension, while the UK has assumed a more outlying position. This suggests that the political contours of the European social dimension will not change once the UK leaves the EU and that the political ideology of neoliberalism transcends the influence of Westminster and has deep roots across the EU. Developments within the European social dimension therefore have strong echoes with other policy areas in two aspects. First, the influence of the UK shifting from having a central role in the EU to one of a more outlying position in policy developments (see Roederer-Rynning \& Matthews, 2019, in this thematic issue); and second, Brexit will not make EU policies less neoliberal (De Ville \& Siles-Brügge, 2019; Price, 2019, in this thematic issue).

The second section of this article outlines the nature of the European social dimension, the shifting political contours of the field up until 2010, and the UK's role in their creation. The third section focuses on the likely nonimpact the UK's departure from the EU will have on the future of the European social dimension.

\section{The Political Contours of the European Social Dimension and the UK's Role in Their Creation}

\subsection{The European Social Dimension in Context}

Before explaining the nature of political contestation around the European social dimension, we first need to understand what it is. EU employment and social policy, commonly referred to as European social dimension, is not a transnational welfare state that supersedes the employment and social policies of the Member States. Rather its purpose is to: regulate and coordinate those policy areas related to the free movement of workers, such as social security; harmonise policy areas which may distort competition, such as health and safety at work; provide for EU level social dialogue; and to provide a framework within which the Member States should reform and modernize their welfare policies in the context of contemporary economic and social challenges. To realise these very specific competences and functions, the $\mathrm{EU}$ uses a mixture of governance instruments such as conventional directives and regulations, as well as legally non-binding instruments such as the Open Method of Coordination (OMC; Ter Haar \& Copeland, 2010). Broadly speaking, directives and regulations are used in policy areas that coordinate social security and those that aim at preventing a distortion of competition. Gender equality also falls under the latter category, but over the last three decades the EU has broadened its equality remit by including all forms of anti-discrimination. In the areas of pension reform, employment, education and training, healthcare, wages, and poverty and social exclusion, the EU predominantly utilizes the OMC. This governance process sees the EU set benchmarks or targets, such as the Lisbon Strategy target of an EU employment rate of 70 per cent by 2010, and the Member States commit themselves to undertake the necessary reforms to achieve them. While this is a legally non-binding commitment, governments are encouraged to make progress by annual reporting, peer review, and the issuing of County Specific Recommendations from the Council and the Commission in areas of policy weakness.

Similar to other EU policy areas, the European social dimension suffers from an expectations-capability gap. Eurostat data show that EU citizens are supportive of the EU doing more in the field. Meanwhile, Daly (2007, p. 2) describes integration in the field as 'fitful' - that is, periods in which intense amounts of political activ- 
ity are then followed by very little integration momentum. Over the last three decades the politics and ideology of the European social dimension has fundamentally shifted. Following the signing of the Single European Act, the concept of a social dimension was touted by then President of France, François Mitterrand, and taken up by the then President of the European Commission, Jacques Delors (Copeland, 2014, pp. 11-12). The idea was to provide a counterweight to neoliberal-driven economic integration and the free-market vision of Europe whereby workers' rights were enshrined in law and social benefits were harmonized and provided on a Europe-wide basis. This vision was inspired by post war Keynesian social democracy and would serve to ensure that members of the then European Economic Community (EEC) would not gain a competitive advantage by liberalising labour law and cutting levels of taxation (and thereby welfare payments). However, from the mid-1990s onwards this vision was slowly replaced by one in which the centre-left accommodated neoliberalism and the balancing of the neoliberal Single European Market with a Keynesian European social dimension failed to take hold. The fundamental purpose of the European social dimension is therefore to restructure and reform the post-war Keynesian social democratic welfare state to ensure that the welfare states of the EU's Members are compatible with the neoliberal logic of the Single European Market. That logic being one in which taxes are cut; the role of the state reduced; state assets privatised; a deregulation of business and finance; a priority given to low inflation rather than low unemployment; the opening up domestic markets to international capital and trade; and an increasingly important role within the economy for migrant workers (Harvey, 2005). In the context of the welfare state this represents a shift in purpose from one in which citizens are protected from the market via policies of de-commodification, to one in which the welfare state supports and extends the reliance of individuals on the market via policies that deepen processes of commodification. In an EU context, this manifests itself in the shift from 'passive benefits', such as unconditional receipt of unemployment benefits, to active labour market policies (ALMPs). ALMPS introduce welfare benefit conditionality whereby the unemployed receive benefits on the condition that they search for work or participate in education and training, even if there are very few jobs available. Meanwhile, the liberalization of labour market regulation and a flexible employment regime serves to encourage employers to hire workers. The rights of ordinary workers are continuously reduced to remove labour market 'rigidities' and make labour behave, in the words of Karl Polanyi (2001), as if it were a true commodity attempting to find its natural price. The EU and its Member States support individuals during this process, but such support is conditional on a process of accepting increased commodification of everyday life. The neoliberal welfare state is therefore one in which individuals weather the peaks and troughs of the economic growth cycle, while elected governments enable the market, and labour, to function correctly.

\subsection{The Role of the UK}

The signing of the Single European Act in 1986 represents a significant turning point in the process of European integration, as it aimed to both deepen and widen the integration of the EEC (Armstrong \& Bulmer, 1998; Nugent, 1999). The Act aimed to complete the Internal Market for physical goods with the removal of all barriers and tariffs for trade, introduced some changes to the Brusselsdecision making processes, such as in introduction of Qualified Majority Voting in the Council for some policy areas, as well as enhanced powers for the European Parliament. The achievement of the Single European Act was to be secured by the deregulation, liberalisation and sometimes re-regulation of the European economy, thereby representing a fundamental ideological shift of the EEC away from post-war Keynesianism towards neoliberalism. Meanwhile, the political momentum surrounding the Act created a 'spill over' effect into policy areas beyond physical goods, such as telecommunications and air transport. However, the emergence and eventual dominance of neoliberalism to guide the process of European integration was by no means a given, as throughout the 1980s and early 1990 s there was political contestation surrounding how best to move forward, as demonstrated by the vision put forward by Jacques Delors.

The UK has played a crucial role in forging the political contours of the European social dimension and thwarting a social dimension that counterbalanced the Single European Market. When Prime Minister Margaret Thatcher said in her 1988 Bruges speech 'we have not successfully rolled back the frontiers of the state in Britain, only to see them re-imposed at a European level with a European super-state' (Thatcher, 1988) she was reacting, not just to what she regarded as creeping EU federalism, but also to the policies of the European Community such as those that aimed to create a European social dimension as a counterweight to the Single European Market. In 1989 the governments of the Member States, with the exception of the UK, adopted the Community Charter of Fundamental Social Rights of Workers, heralded as the European social dimension equivalent of the Single European Act. At the Maastricht Treaty Negotiations, the Community Charter was given full legal recognition, but continued opposition from the UK resulted in the Charter being annexed to the Treaty, thereby permitting integration in the field without the UK. The Social Chapter, as it was known at Maastricht, included policy areas such as the promotion of employment, proper social protection, social dialogue, and the combating of poverty and social exclusion.

The UK's reluctance to integrate in the field clearly put a break on the emergence of a more social democratic-inspired European social dimension (Velluti, 
2010, p. 114). The UK thwarted the political momentum and ensured that policy issues remained on the margins of the integration process. Without one of the EU's largest Member States involved in the process of integration, there were concerns that the UK may gain a competitive advantage within the EU should the other 11 Member States agree policy that would impose restrictions and extra costs on labour. However, this did not mean that the UK was exempt from all policy developments in the field. From the late 1980s onwards the $\mathrm{EEC} / \mathrm{EU}$ agreed a series of directives in the field of health and safety at work, an EU policy competence that falls under the Treaty provisions of the Single European Market and not the European social dimension. The adoption of the Single European Act brought health and safety at work into the Treaty for the first time and policy is agreed by qualified majority voting. Despite the UK signing the Single European Act, it did not take long for opposition to mount in Westminster against the policy competence. One such health and safety directive, the 1993 Working Time Directive (WTD) proved a step too far for the government of John Major (1990-1997). The directive limits the number of working hours an individual can work to 48 per week (averaged over a three-month reference period), as well as provisions for holiday entitlement and rest periods. The original justification for the directive had been that working time was a health and safety issue and that working excessive hours over a prolonged period was detrimental to health. The Major government argued that it was an employee's fundamental right to choose the amount of hours worked and that the WTD would reduce the flexibility of the UK's labour market. The directive therefore included the opt-out clause which permits Member States not to apply the maximum 48-hour limit on the basis of voluntary agreement between employers and employees. Despite the opt-out, the UK government remained disgruntled, prompting it to challenge the legal basis of the WTD in the ECJ. The UK government argued that the directive was not a health and safety directive, which permitted decisions to be taken in the Council by qualified majority voting and thereby overruling a British veto during unanimity voting (Blair \& Leopoid, 2001). This view was not shared by the ECJ which in 1996 ruled that the WTD was a health and safety issue and that the UK was required to implement it. A reluctant Labour Government implemented the directive in 1998, although it decided to use the opt-out for all sectors of the economy. Despite opting out of the social dimension, the UK therefore still found itself embroiled in negotiations surrounding health and safety legislation.

While the political agency of the UK thwarted efforts to move forward with a Keynesian-inspired European social dimension, it is important to understand how this agency interacted with the institutional context within which it was situated. Scharpf $(1999,2006)$ has argued that the institutional architecture of the EU combined with the political, economic and institutional heterogeneity of the Member States creates a structural asymmetry between the policies of liberalisation and those of social regulation. Central to this observation is Scharpf's distinction between negative and positive integration. Negative integration describes the elimination of tariffs, barriers to trade, and distortions to free competition such as state aid-it is almost always market-creating. It is driven by the ECJ based on the four freedoms (goods, services, capital, people) as well decisions taken by the European Commission in competition law. By contrast positive integration is understood as the exercise of economic and regulative competences at the supranational level and can either be market-making or market-correcting. Positive integration is a political decision-making mode that requires a broad consensus among national governments and the European Parliament (Scharpf, 1999, pp. 50-51). Given that such a broad consensus is difficult to obtain under qualified majority voting, especially in a diverse union of Member States with different production regimes, political comprises often only represent the 'lowest common denominator' (Höpner, 2013, pp. 75-76; Scharpf, 2006, p. 851; Seikel, 2016, p. 1402). In short, market-correcting policies, including those in the European social dimension, are unlikely to emerge from Brussel and those that are proposed are most likely to be watered down to become more marketmaking. The political agency of the UK combined with institutional and political configuration of the EU thwart a Keynesian-inspired European social dimension and enabled the creation of one that is broadly underpinned by neoliberalism.

1997 represents a step-change for the European social dimension in two ways. First, the 1997 general election brought the Labour Party, under Tony Blair, to power in the UK. In its election manifesto it promised to be a more constructive partner in the EU than its predecessors and it signed the UK into the Social Chapter (Barnard, 1997). This move paved the way for the Social Chapter to be fully incorporated into the main body of the Treaty at the Amsterdam Treaty changes (1997). It was greeted with great optimism in the other European capitals and was thought to signify a turning point not just in UK-EU relations, but for the European social dimension as well. Second, the Treaty changes agreed at Amsterdam shifted the governance tools used within the European social dimension. Amsterdam marks the move away from directives with their harmonizing effect, to the legally non-binding forms of governance, known as the OMC from 2000 onwards. The European Employment Strategy, launched in 1997, was in part, influenced by the 1995 EU accession of Austria, Finland and Sweden-three Member States that have some of the most generous welfare states on the Continent. The use of this flexible mode of governance was regarded as a pragmatic solution to further integrate in the field which is characterised by significant differences between the Member States (Caune, Jacquot, \& Palier, 2011).

While most of the literature on the European Employment Strategy highlights its innovative form of 
'new' governance (Trubek \& Mosher, 2003; Zeitlin, 2009), it is equally important to recognise the politics of the European Employment Strategy and the shift of thinking within the mainstream European left. The new left, which emerged across Europe from the mid-1990s onwards, represents a radically different ideology to postwar Keynesian social democracy, and is more compatible with neoliberalism and the Single European Market. The European left was therefore playing catch-up with developments in the Single European Market and sought to bridge the divide between neoliberalism and postwar social democracy. The 'Third Way' vision of political economy, as it was known, embraced neoliberalism, albeit to intervene to support economic and social fairness by ensuring that individuals had the necessary opportunities and skills to participate in the market. In this regard, the Third Way was about embracing the neoliberal market while simultaneously reducing some of the more extremes of purely commodified labour markets (cf. Giddens, 1998). For the European social dimension, this meant reforming the EU labour market to remove rigidities and to ensure maximum flexibility so that labour would behave as though it was any other commodity to be bought and sold. Meanwhile, the Keynesian policy of individuals receiving unemployment benefit, regardless of the economic situation, was to be replaced by ALMPs whereby benefit recipients were to receive benefits on the condition that they look for work or engage in education and training programmes. Such policies shift the burden of responsibility for the economic and social situation away from the state and place this onto the individual, regardless of the economic situation. From 1997 onwards, the European social dimension slowly became the EU's transmission belt through which the post-war Keynesian welfare state was to be reformed and replaced with policies of neoliberalism. New Labour's embracing of the European social dimension was therefore an embracing of a policy area that had a near perfect fit with its own domestic political agenda-the UK opted-in to the European social dimension because it would not constrain domestic policy (Hopkin \& van Wijnbergen, 2011).

The launching of the Lisbon Agenda in 2000 built on the optimism and ideology of the European Employment Strategy. Lisbon was the EU's economic and social reform programme for the decade and aimed to modernise the structural pillars of the European economy to become: 'the most competitive and dynamic knowledgebased economy in the world capable of sustainable economic growth with more and better jobs and greater social cohesion' (European Council, 2000). In the European social dimension this involved reforms and the modernisation of pensions, employment protection, employment policies, education and training systems, and improvements to fields such as gender equality and social exclusion. Inspired by the governance processes used within the European Employment Strategy, these policy areas were also to use the now referred to OMC. The Lisbon Agenda further emphasised the centre-left's vi- sion for a European social dimension, which continued to shift the political contours of the debate from regulation, harmonisation, and decommodification, to that of de-regulation, flexibility and commodification, albeit with state support. A lack of progress surrounding the various targets of the Lisbon Agenda and the changing political constellations of the EU resulted in the need to relaunch the strategy in 2005. The incoming Barroso Commission (2004-2009) commissioned a report by the former Dutch Prime Minister, Wim Kok, to review the Agenda. The report argued that the Lisbon Agenda was failing to make progress because of policy overload, poor coordination, conflicting priorities, and weak national ownership. With the centre-right now in a majority in the European Council (14 of 25 states) key heads of government (Tony Blair of the UK, Silvio Berlusconi of Italy, Jean Claude Juncker of Luxembourg) in conjunction with the Commission, formed alliances to radically reform the Lisbon Agenda (James, 2012, pp. 18-20). The Lisbon Strategy or Lisbon II as it was sometimes referred to, simplified its aim to improve 'Growth and Jobs', and limited the number of objectives and governance structure (Ter Haar \& Copeland, 2010, pp. 287-288). Lisbon II signifies the end of the centre-left experimentation with the European social dimension and shifted the reform agenda to a much deeper process of commodification. Under Lisbon II social cohesion became a simple function of, and dependent upon, progress made within the economy and the policy areas of employment and education were coupled and integrated with the Broad Economic Policy Guidelines to improve the synergies and linkages between macroeconomic policy and the reform of certain aspects of the welfare state. Meanwhile, the policy areas of social inclusion, healthcare, and pensions were relegated in importance and were side-lined (Tholoniat, 2010).

Against this backdrop the number of Directives proposed for the European social dimension stalled. One of the most high-profile fallouts was that of the revision of the WTD. Within the original directive a review clause was included requiring the opt-out and the reference period to be reviewed before 2003, by which point it was hoped that the UK would have reduced its long hours working culture and that the opt-out could be removed. Furthermore, two ECJ rulings (SiMAP and Jaeger) had questioned whether the inactive part of on-call time was to be considered as working time. The ECJ concluded that all on-call time was to be considered as working time, however, the majority of EU Member States had already interpreted the original Directive as stipulating that the inactive part of on-call time was not working time. This issue was therefore also part of the renegotiations of the Directive. Following the release of a revised draft directive by the European Commission in 2004, the UK found itself in a minority position within the Council regarding the removal of the opt-out. However, over the following three years the diplomatic efforts of the UK resulted in it and its new allies forming the majority posi- 
tion within the Council. The political negotiations took numerous twists and turns, but it is estimated that the UK dedicated no less than 200 civil servants to the task of securing a revised Directive that included the optout. Its position was bolstered by the 2004 enlargement with 8 of the 10 new Member States having transitioned from state-socialism to neoliberal capitalist democracy. Furthermore, they were also keen to protect their comparative advantage of being a low-cost base for production within the EU. With a stalemate in the European Council, and between the Council and the European Parliament, the latter who wanted to remove the optout, a revised Directive was eventually shelved, the UK having ensured that maximum flexibility within the directive was maintained (Copeland, 2014, pp. 79-87).

\section{The Contours of a Post-Brexit European Social Dimension}

Since 2010 the EU has strengthened the neoliberal reform integration that emerged during the Lisbon decade within the European social dimension, but importantly, has done so without the participation of the UK. Since 2010 successive UK governments have strategically withdrawn from engaging with the EU's social dimension. This stands in stark contrast to the New Labour Governments (1997-2010) that aimed to shape and thereby determine EU policy in the European social dimension. This strategic withdrawal was based on the position of the Conservative Party, which formed various UK governments from 2010 onwards. In its 2010 election manifesto the Conservative Party, traditionally a Eurosceptic party, argued that the 'steady and unaccountable intrusion of the European Union into almost every aspect of our lives has gone too far' (Conservative Party, 2010). It pledged to return powers from the EU including the Charter on Fundamental Rights, criminal justice law, and social and employment legislation. This played into long held Conservative Party belief that the purpose of the EU is to serve as a free trade area and that political union, as well as attempts to harmonise or coordinate policy outside of the Single European Market, represent an infringement upon national sovereignty. Failing to win an outright majority in the 2010 election, the Conservative Party formed a coalition government with the minority Liberal Democrat party-historically a pro-EU party-in May of that year. The Government appointed lain Duncan Smith, regarded as an ardent Eurosceptic in the Conservative Party, as the Secretary of State for Work and Pensions. This corresponded with the final negotiations and preparations for the successor to the Lisbon Strategy, Europe 2020, which was agreed in the European Council in June 2010. Europe 2020 includes several quantitative targets for the European social dimension: for employment the objective is to increase the number of individuals in work to 75 per cent (age 20-64); in education and training Member States are required to reduce the school dropout rate to less than 10 per cent and to increase the share of the population aged 30-34 who have completed tertiary education to at least 40 per cent; for poverty and social exclusion the target is to reduce the number of poor people across the EU by 20 million. Note that in the latter policy area this is the first quantitative target in the field and on paper represents significant progress, even though the EU's legal competence has remained unchanged. While the UK's aim to repatriate powers from Brussels in the European social dimension ultimately failed, from 2010 onwards the UK refused to set quantitative targets for employment and social aspects of Europe 2020. As the UK retreated, the Government of Prime Minster David Cameron argued that the EU's response to the Eurozone crisis was not its concern and that EU governance arrangements should focus on Eurozone Members (Copeland, 2016).

The EU attempted to resolve the Eurozone crisis by pursuing austerity-a policy in which EU Member States voluntarily deflate their economies and restore competitiveness by reducing wages, increasing taxation, liberalising labour markets, and slashing public spending by cutting national budgets (Blyth, 2013). The latter may result in a reduction in the size of the public sector, cuts to education, healthcare, pensions, and other welfare benefits. For Ladi and Graziano (2014) EU driven austerity should be conceived as 'fast forward Europeanization' (read neoliberalism) in which EU states that had dragged their feet on domestic reforms during the previous decade were required to undertake shock therapy and rapidly reform their economies under pure market conditions. To govern this agenda the EU introduced the European Semester-an annual governance cycle in which the performance of the Member States with regard to the tightened rules of the Stability and Growth Pact, which require more stringent budgetary discipline, are coupled with the policy objectives of Europe 2020. This coupling is intended to be more pronounced than the governance arrangements of Lisbon II and represents a significant change to EU policy coordination with the overall emphasis being on budgetary discipline and fiscal consolidation (see Armstrong, 2012). Prior to the commencing of a Semester cycle, Eurozone Members are required to submit their national budgets for approval to the Commission in October before they are finalised at national level. The Commission is then able to assess the draft budgets in accordance with the Stability and Growth Pact, as well as the Country Specific Recommendations that were introduced in the previous year. The cycle of the European Semester begins in November when the Commission publishes its Annual Growth Survey and the Alert Mechanism Report. The former sets out the Commission's economic and social priorities for the next 12 months. Once these have been agreed by the Spring Council, Member States report their progress of the Europe 2020 guidelines in a National Reform Programme. In areas of policy weakness, the European Commission and the European Council formulate Country Specific Recommendations for each of 
the Member States. The Post-2010 EU governance arrangements blend neoliberalism with German-led ordoliberalism and this blending has continued the pathdependency of the political economy of European integration (Blyth, 2013). The main difference between the two is that while neoliberalism proposes a minimal state with market-self regulation, ordoliberalism proposes a minimal state that regulates markets to maximise competition and to protect and defend liberty from the emergence of monopolies. Ordoliberalism is therefore a more rules-based system of market governance than the laissez-faire of neoliberalism, but in terms of processes of commodification, it is no different as they both prioritise individual freedom, the dominance of the market, and hyper commodification (Wilkinson, 2019).

In the context of the European social dimension, Europe 2020 and the European Semester construct an ideological straight-jacket in which employment and social policy reforms need to conform to the market-driven logic of European integration. With enhanced surveillance and restrictions on government spending, as well as a potential financial penalty should the rules of the Stability and Growth Pact be breached, governments are unlikely to undertake ambitious social and employment policy reforms that may be costly in the short run, but provide long-term benefits, for fear of the repercussions. Meanwhile, as levels of taxation (income and corporation tax) are a competitive space within the EU, the race to the bottom between the Member States to attract and maintain capital, combined with an ageing population that is more costly to support, result in there being fewer resources for employment and social policy. Faced with these restraints, governments and the EU aim to ensure that there are as few people dependent on the welfare state as possible, particularly of working age. This is achieved by intensifying ALMPs and the commodification of individuals to make labour more attractive to hire. The belief here is that pure markets will improve efficiency and thereby economic growth, but the reality is very different as it forces individuals to behave as though they are void of emotions, to be bought or sold on the market a kin to any other good for sale. This ignores some of the key features that make us human beings.

The EU's Youth Guarantee, launched in 2013, serves as a classic example of such a policy and illustrates the direction the EU has been travelling since UK political agency has been in decline. The Youth Guarantee involved the ring-fencing of $€ 6.4$ billion of the European Social Fund (ESF) to tackle an EU youth unemployment rate of 23.9 per cent (European Council, 2013). Under the Youth Guarantee, individuals below the age of 25 who have been unemployed for four months since leaving formal education should be provided with a job offer, apprenticeship, traineeship of continued education. The ESF provides partial funding for the scheme, while the remainder is matched by the Member States. The Youth Guarantee focuses on improving the supply of labour, but the Member States that had the highest lev- els of youth unemployment were experiencing a lack of domestic demand in their economies, the latter having been suppressed by EU-driven austerity. There will still be insufficient employment opportunities once such programmes finish with the result being that the unemployed are simply churned around a system unable to find jobs. Meanwhile, the excess supply of labour will result in a downward pressure on wages which may stimulate employment in the long-term, but individuals will ultimately suffer under a system of self-imposed hyper competitiveness. Towards the end of the second Barroso Commission (2009-2014), the European Semester was producing more Country Specific Recommendations that related to the European social dimension. However, the claim that this resulted in a 'partial but progressive socialization of the European Semester' (Zeitlin \& Vanhercke, 2017 ) is conditional and contingent on policies that deepen market forces and therefore the commodification of individuals (Copeland \& Daly, 2018). In other words, the European social dimension has increased its profile within the European Semester, but the trade-off has been to produce policies that continue to correspond with a neoliberal vision of the welfare state.

This path-dependency of integration has continued under the Juncker Commission (2014-2019). While Juncker has been able to raise the profile of the European social dimension, the content of policy outcomes remains in accordance with the EU's now path dependent approach in the field, although one exception to this has been the revision of the Posting of Workers Directive (2018). While it is not possible to go into detail on this issue here, it should be noted that the revised Directive aims to close several loop-holes within the original directive (1996) whereby temporary workers from the East are able to undercut the wages of local workers in the West (see Picard \& Pochet, 2018). However, beyond this the political economy of the European social dimension remains intact. For example, the European Commission's Reflection Paper on Harnessing Globalisation (European Commission, 2017) calls for a better distribution of the benefits of globalisation, coupled with effective social protection, to help people find a decent job and adapt to change. 'Effective social protection' clearly refers to ALMPs, meanwhile the purpose of social protection is to ensure that people find work and remain employed. There is nothing redistributive in terms of income nor genuinely protective of workers within this approach. In relative terms, the Juncker Commission has increased the number of employment and social Country Specific recommendations made within the European Semester, but this has not fundamentally changed the political contours of them (see Clauwaert, 2018). These developments have been guided by the 'social investment' paradigm, which gained traction during the final days of the Barroso II Commission. In its purest form, social investment is about distinguishing between welfare spending that enhances productive capacity, such as education and training, and that which is passive and spent 
on consumption, such as pensions and spending on elderly care (Nolan, 2013). In an EU context this means ensuring that welfare spending produces a 'return on investment'. Social considerations are therefore, at best, a secondary priority, if at all. The market-driven process of reforming European welfare states also underpins the Juncker Commission's most significant achievement for the European social dimension-the European Pillar of Social Rights. With much fanfare the Pillar was launched in November 2017 and is a declaration of social and employment rights that aims to feed into the European Semester. The declaration is legally non-binding and contains 20 principles and rights that are grouped into three themes: (1) equal opportunities and access to the labour market; (2) fair working conditions; and (3) social protection and inclusion. The pillar represents an amalgamation of social rights already guaranteed in the Charter of Fundamental Rights of the European Union, albeit updated to: (1) reflect changes in the labour market; (2) the existing employment and social policy competences and activities of the EU; and (3) a few policy issues that attempt to both define and steer the European social dimension within the European Semester. The Pillar contains very few rights that are new and despite it covering issues such as housing and homelessness, access to essential services, and childcare and support for children, the broader set of social rights are obtained via an individual's participation in the labour market and hence their commodification.

\section{Conclusion}

The UK has been a pivotal outlier in the construction of the European social dimension, first, by limiting the emergence of the post-war Keynesian social democratic vision that emerged in the late 1980s and early 1990s, and second, by becoming supportive of a neoliberal vision for the field throughout 1997-2010. The thwarting of a social democratic European social dimension has clearly been aided by the EU's tendency towards negative integration, but at the crucial moment when it was being constructed, the UK proved itself to be a formidable force to block developments. Meanwhile, developments since 2010 when the EU further consolidated neoliberalism within the social dimension, and UK political agency was in decline, suggest that the political contours of the European social dimension will not change once the UK leaves the EU. The power of neoliberal ideas, sometimes blended with German-led ordoliberalism, to reform European welfare states therefore transcends the agency of the UK and will continue long after the UK's withdrawal from the EU. At its very core, as well as encouraging the free movement of workers, by guaranteeing rights and access to the welfare state, the European social dimension is designed to reform EU welfare states to ensure that the market plays an ever greater role in determining outcomes for policy problems. In this respect, the aim is to ensure that there is limited room for policies to decommodify individuals, thereby making labour behave as though it is just another component of the Single European Market. Post Brexit, while there may be increased political activity within the European social dimension, its path-dependent trajectory will ensure that the field will not fundamentally alter. Meanwhile, the pursuit of this agenda within the EU is undermining the very integrity of the EU. The current rise of populism and nationalism within the EU owes much to the EU's neoliberal agenda that continuously promotes market-driven solutions for economic and social problems (Eatwell \& Goodwin, 2018, pp. 177-223). Commodifying individuals to such an extreme level, as noted by Karl Polanyi (2001), will produce a backlash, as neoliberalism aims to de-humanise and thereby commodify emotionally intelligent human beings. A problem is that the UK's attempt to leave the EU will not alter the political economy of European integration.

\section{Acknowledgments}

I would like to thank Ferdie De Ville, Gabriel Siles-Brügge, the other contributors of this thematic issue, and three anonymous reviewers for their helpful comments on drafts of this article. A special thank you to Andrew Clark for proof-reading this article, as well as QMUL for paying the cost of publication. This article is dedicated to all individuals who believe in a more equal and fair world.

\section{Conflict of Interests}

The author declares no conflict of interests.

\section{References}

Armstrong, K. (2012). The Lisbon Strategy and Europe 2020: From the governance of coordination to the coordination of governance. In P. Copeland \& D. Papadimitriou (Eds.), Evaluating the EU's Lisbon Strategy (pp. 208-228). Basingstoke: Palgrave Macmillan.

Armstrong, K. A., \& Bulmer, S. J. (1998). The governance of the single european market. Manchester: Manchester University Press.

Barnard, C. (1997). The United Kingdom, the 'Social Chapter' and the Amsterdam Treaty. Industrial Law Journal, 26(3), 275-282.

Blair, A., \& Leopoid, J. (2001). An awkward partner? Britain's implementation of the working time directive. Time and Society, 10(1), 63-76.

Blyth, M. (2013). Austerity: The history of a dangerous idea. Oxford: Oxford University Press.

Caporaso, J. A., \& Tarrow, S. (2009). Polanyi in Brussels. International Organization, 63(4), 593-620.

Caune, H., Jacquot, S., \& Palier, B. (2011). Social Europe in action: The evolution of EU policies and resources. In P. Graziano, S. Jacquot, \& B. Palier (Eds.), The EU and the domestic politics of welfare state reform (pp. 
19-47). Basingstoke: Palgrave Macmillan.

Clauwaert, S. (2018). The country-specific recommendations (CSRs) in the social field: An overview and comparison (update including the CSRs 2018-2019. Brussels: European Trade Union Institute.

Conservative Party. (2010). Invitation to join the government of Britain. London: The Conservative Party.

Copeland, P. (2014). EU enlargement, the clash of capitalisms and the European social dimension. Manchester: Manchester University Press.

Copeland, P. (2016). Europeanization and de-Europeanization in UK employment policy: Changing governments and shifting agendas. Public Administration, 94(4), 1124-1139.

Copeland, P., \& Daly, M. (2018). EU social policy and the European semester. Journal of Common Market Studies, 56(5), 1001-1018.

Daly, M. (2007). Whither EU social policy? An account and assessment of developments in the Lisbon social inclusion process. Journal of Social Policy, 37(1), 1-19.

De Ville, F., \& Siles-Brügge, G. (2019). The impact of Brexit on EU trade policy. Politics and Governance, 7(3), 7-18.

Eatwell, R., \& Goodwin, M. (2018). National populism: The revolt against liberal democracy. London: Penguin Random House UK.

Esping-Andersen, G. (1990). The three worlds of welfare capitalism. Princeton, NJ: Princeton University Press.

European Commission. (2017). Reflection paper on harnessing globalization (Com (2017) 240). Brussels: European Commission.

European Council. (2000). Lisbon European council 23 and 24 March 2000: Presidency conclusions. European Parliament. Retrieved from http://www. europarl.europa.eu/summits/lis1_en.htm

European Council. (2013). Council recommendation of 22 April 2013 on establishing a youth guarantee (2013/C 120/01). Brussels: European Council. Retrieved from https://eur-lex.europa.eu/LexUriServ/LexUriServ. do?uri=OJ:C:2013:120:0001:0006:EN:PDF

Giddens, A. (1998). The third way: The renewal of social democracy. Cambridge: Polity Press.

Harvey, D. (2005). A brief history of neoliberalism. Oxford: Oxford University Press.

Hopkin, J., \& van Wijnbergen, C. (2011). Europeanization and welfare state change in the UK: Another case of 'fog over the channel'? In P. Graziano, S. Jacquot, \& B. Palier (Eds.), The EU and the domestic politics of welfare state reform (pp. 53-76). Basingstoke: Palgrave Macmillan.

Höpner, M. (2013). Soziale Demokratie? Die polit-ökonomische Heterogenität Europas als Determinante des demokratischen und sozialen Potenzials der Europäischen Union [Social democracy? The political-economic heterogeneity of Europe as a determinant of the democratic and social potential of the European Union] Europarecht,
2013(1), 69-89.

James, S. (2012). The origins and evolution of the Lisbon agenda. In P. Copeland \& D. Papadimitriou (Eds.), Evaluating the EU's Lisbon strategy (pp. 8-28). Basingstoke: Palgrave Macmillan.

Ladi, S., \& Graziano, P. R. (2014). Fast-forward Europeanization: Welfare state reform in light of the Eurozone crisis. In R. Coman, T. Kostera, \& L. Tomini (Eds.), Europeanization and European integration. Palgrave studies in European Union politics (pp. 108-126). Basingstoke: Palgrave Macmillan.

Nolan, B. (2013). What use is 'social investment'? Journal of European Social Policy, 23(5), 459-468.

Nugent, N. (1999). The politics and government of the European Union (4th ed.). Basingstoke: Macmillan.

Peters, G. B., Pierre, J., \& King, D. S. (2005). The politics of path dependency: Political conflict in historical institutionalism. The Journal of Politics, 67(4), 1257-1300.

Picard, S., \& Pochet, P. (2018). The posting of workers saga: A potted version of the challenges engulfing social Europe (No. 6/2018). Brussels: European Trade Union Institute for Research. http://dx.doi.org/ $10.2139 /$ ssrn.3211853

Polanyi, K. (2001). The great transformation: The political and economic origins of our time. Boston, MA: Beacon Press.

Price, S. (2019). The impact of Brexit on EU development policy. Politics and Governance, 7(3), 72-82.

Roederer-Rynning, C., \& Matthews, A. (2019). What common agricultural policy after Brexit? Politics and Governance, 7(3), 40-50.

Scharpf, F. W. (1999). Governing in Europe: Effective and democratic? Oxford: Oxford University Press.

Scharpf, F. W. (2006). The joint-decision trap revisited. Journal of Common Market Studies, 44(4), 845-864.

Seikel, D. (2016). Flexible austerity and supranational autonomy: The reformed excessive deficit procedure and the asymmetry between liberalisation and social regulation in the EU. Journal of Common Market Studies, 54(6), 1398-1416.

Ter Haar, B. P., \& Copeland, P. (2010). What are the future prospects for the European social model? An analysis of EU equal opportunities and employment policy. European Law Journal, 16(3), 273-291.

Thatcher, M. (1998). Speech to the College of Europe ('The Bruges Speech'). The Margaret Thatcher Foundation. Retrieved from https://www. margaretthatcher.org/document/107332

Tholoniat, L. (2010). The career of the open method of coordination: Lessons from a 'soft' EU Instrument. West European Politics, 33(1), 93-117.

Trubek, D. M., \& Mosher, J. S. (2003). New governance, employment policy, and the European social model. In J. Zeitlin \& D. M. Trubek (Eds.), Governing work and welfare in a new economy: European and American experiments (pp. 33-58). Oxford: Oxford University Press. 
Velluti, S. (2010). New governance and the European Employment Strategy. London: Routledge.

Wilkinson, M. (2019). Authoritarian liberalism in Europe: A common critique of neoliberalism and ordoliberalism. Critical Sociology. Advance online publication. https://doi.org/10.1177/0896920519837325

Zeitlin, J. (2009). The open method of coordination and reform of national social and employment policies:
Influences, mechanisms, effects. In M. Heidenreich \& J. Zeitlin (Eds.), Changing European employment and welfare regimes (pp. 53-76). London: Routledge.

Zeitlin, J., \& Vanhercke, B. (2017). Socializing the European semester: EU social and economic policy coordination in crisis and beyond. Journal of European Public Policy, 25(2), 149-174.

\section{About the Author}

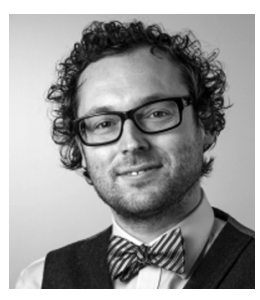

Paul Copeland is Senior Lecturer (Associate Professor) of Public Policy at Queen Mary University of London. His research specialises in the political economy of European integration, particularly in the context of EU employment and social policy, and the UK's relationship with the EU. His latest research monograph Governance and the European Social Dimension: Politics, Power and the Social Deficit in a Post-2010 EU will be published in 2020 (Routledge). 